\title{
B-Elemene, a novel plant-derived antineoplastic agent, increases cisplatin chemosensitivity of lung tumor cells by triggering apoptosis
}

\author{
QINGDI Q. LI ${ }^{1,2 *}$, GANGDUO WANG ${ }^{1 *}$, MANCHAO ZHANG ${ }^{1}$, \\ CHRISTOPHER F. CUFF ${ }^{1}$, LAN HUANG $^{3}$ and EDDIE REED ${ }^{4}$

\begin{abstract}
${ }^{1}$ The Mary Babb Randolph Cancer Center and Department of Microbiology, Immunology and Cell Biology, Robert C. Byrd Health Sciences Center, West Virginia University School of Medicine, Morgantown, WV 26506; Berkeley Heights, NJ 07922; ${ }^{4}$ Mitchell Cancer Institute, University of South Alabama, Mobile, AL 36604, USA
\end{abstract} \\ ${ }^{2}$ The National Institutes of Health, Bethesda, MD 20892; ${ }^{3} \mathrm{HYWE}$ Pharmaceutical Corporation, 426 Mountain Avenue,
}

Received January 14, 2009; Accepted April 6, 2009

DOI: 10.3892/or_00000420

\begin{abstract}
Elemene, a new plant-derived anticancer agent with low toxicity, has been reported to be effective in the treatment of leukemia and solid tumors. In the current study, we explored the therapeutic application of $B$-elemene in sensitizing lung cancer cells to cisplatin. B-Elemene considerably enhanced the inhibitory effect of cisplatin on cell proliferation in a time- and dose-dependent manner in the human non-small cell lung cancer (NSCLC) cell lines H460 and A549. Furthermore, this effect of B-elemene on cisplatin activity occurred through the induction of apoptosis in NSCLC cells, as assessed by an ELISA-based assay, TUNEL assay and annexin V binding assay. Consistent with these results, the protein levels of Bax and phospho-Bcl-2 increased and those of Bcl-2 and XIAP decreased in cells treated with $B$-elemene in combination with cisplatin, compared with the levels in cells treated with either agent alone. Finally, $\beta$-elemene augmented the cisplatin-induced increases in caspase- $3,-7,-9$ and -10 activities and cleaved caspase-3, -9 and poly(ADP-ribose) polymerase levels in NSCLC cells. These observations suggest that $\beta$-elemene sensitizes NSCLC cells to cisplatin via a mitochondriamediated intrinsic apoptosis pathway involving Bcl-2 family proteins and IAPs (inhibitor of apoptosis proteins). Our data provide a rationale for developing a combination of $\beta$-elemene and cisplatin as a regimen for the treatment of lung carcinoma and other cisplatin-resistant tumors.
\end{abstract}

Correspondence to: Dr Qingdi Q. Li, The National Institutes of Health, Building 10, Room 11N234, Bethesda, MD 20892, USA E-mail: liquenti@mail.nih.gov

${ }^{*}$ Contributed equally

Key words: B-elemene, plant drug, Chinese medicine, cisplatin, lung cancer, apoptosis

\section{Introduction}

Lung cancer currently claims more than 165,000 lives a year in the United States, making it the leading cause of cancer mortality among both men and women. Approximately $85 \%$ of lung cancer cases are diagnosed as non-small cell lung cancer (NSCLC), and the 1-year survival rate for patients with untreated NSCLC is only $10-15 \%$. Early detection and treatment can improve the prognosis, but only $15 \%$ of patients with lung cancer are diagnosed at an early stage (1-3). Most patients with NSCLC present with advanced disease, which may limit their treatment options to surgery or radiation. Nevertheless, more than $80 \%$ of patients with NSCLC are potential candidates for chemotherapy at some time during the course of their disease (3-5).

Platinum-based agents provide the most effective systemic chemotherapy for NSCLC, and cisplatin (cis-diamminedichloroplatinum II) is one of the most important chemotherapeutic agents currently available for cancer treatment (5-8). Cisplatin-based combinations have remained the standard first-line chemotherapy for advanced NSCLC for more than two decades (7-9). Cisplatin not only significantly improves survival rates in patients with NSCLC but also provides symptom relief. Unfortunately, despite its great efficacy, cisplatin is associated with several major problems, including a number of side effects and the development of resistance, which undermine the curative potential of cisplatin $(5,8,10-12)$. Clearly, new approaches such as novel effective drugs with mild toxicities or excellent combination regimens are needed for the treatment of NSCLC.

Elemene (1-methyl-1-vinyl-2,4-diisopropenyl-cyclohexane) is a novel anticancer drug extracted from the traditional Chinese medicinal herb Rhizoma zedoariae. B-Elemene, the active component of elemene, has been used effectively in China to treat certain types of tumors (13-16) and is now being evaluated in clinical trials in the United States. Studies indicate that $B$-elemene is a broad-spectrum anticancer agent, with efficacy in treating leukemia, brain tumor, breast cancer and liver cancer (13-17). Recently, B-elemene has been shown 
to induce tumor cell apoptosis and cell cycle G2/M arrest, as evidenced by DNA ladder formation, morphological alterations and flow cytometric data; these findings suggest that apoptosis and $\mathrm{G} 2 / \mathrm{M}$ arrest triggered by $B$-elemene contribute to its inhibition of cell proliferation (13-18). BElemene has also been shown to decrease the level of Bcl-2, an anti-apoptotic protein (18). Furthermore, B-elemene has low toxicity, is easy to administer, and is well tolerated and accepted by cancer patients $(13,14)$. It has also been demonstrated that $\beta$-elemene does not increase multi-drug resistance $(13,19)$, a major challenge in cancer chemotherapy. Thus, $\beta-$ elemene has the potential to become an important chemotherapeutic agent, although the mechanism underlying its action has not been elucidated $(15,17)$.

Although the specific details are not yet known, it is generally accepted that a variety of stimuli such as stress and drugs trigger apoptosis through pathways involving the mitochondria, which serve as a vital death signal integrator in apoptosis $(20,21)$. The perturbation of mitochondrial membranes and the consequent release of cytochrome $c$ appear to be critical events for apoptosis. The proteins Bax and $\mathrm{Bcl}-2$ have opposing roles in initiating mitochondrial dysfunction and modulating apoptosis $(22,23)$. Bcl-2 is associated with the outer mitochondrial membrane, where it plays a pivotal and overriding protective role by preserving mitochondrial structure and function, thereby preventing the onset of a mitochondrial permeability transition and inhibiting the release of cytochrome $\mathrm{c}$ into the cytosol. In contrast, Bax, a dominant-negative inhibitor of Bcl-2, induces a mitochondrial permeability transition and promotes apoptosis (22-26). Thus, when the level of Bax increases, the mitochondrial membrane becomes permeable to cytochrome c. Upon its release from the mitochondria into the cytosol, cytochrome $\mathrm{c}$ forms an apoptosome complex with Apaf-1, pro-caspase-9 and ATP, leading to the cleavage and activation of caspase-9, which in turn activates downstream effector caspases such as caspase-3 and -7 . Subsequently, the active executioner caspase- 3 cleaves downstream substrates such as poly-(ADPribose) polymerase, which are responsible for the morphological and biochemical changes that are the hallmarks of apoptosis $(20,21,23,27-31)$. In this regard, inhibitors of apoptosis proteins (IAPs) such as X-chromosome-linked IAP (XIAP) have been shown to be important intrinsic regulators of the caspase cascade. The BIR (baculovirus iap repeat) domain of IAP family members can directly bind to and inhibit the activities of caspase-9, -3 and -7 . On the other hand, the activity of XIAP is attenuated upon cleavage by caspase -3 and -7 and can be negatively regulated by the protein Smac, which is released from the mitochondria (32-34).

Previous studies in our laboratory have demonstrated that B-elemene, acting as a single agent, inhibits cell proliferation in lung cancer (18). The present study was undertaken to examine the effect of $\beta$-elemene on cisplatin activity in NSCLC and to determine the mechanism underlying combination chemotherapy with both agents. We show that Belemene increases cisplatin cytotoxicity and enhances cisplatin sensitivity in human NSCLC cells. We also demonstrate that $B$-elemene sensitizes NSCLC cells to cisplatin through a mitochondria-dependent apoptosis pathway. Our data provide a rationale for designing a combinatorial regimen with $B$-elemene and cisplatin for the treatment of lung carcinoma and other tumors.

\section{Materials and methods}

Chemicals and immunoreagents. (-)ß-Elemene (98\% purity) was obtained from Yuanda Pharmaceuticals Ltd., Inc. (Dalian, China). Cisplatin, propidium iodide and glycine were purchased from Sigma-Aldrich (St. Louis, MO). Primary antibodies against Bcl-2, Bax, cytochrome c, caspase-3, caspase-9, XIAP, PARP and $B$-actin, and the HRP-conjugated goat anti-rabbit IgG, HRP-conjugated goat anti-mouse IgG, as well as nitrocellulose, Blotto and chemiluminescence luminal reagents were all from Santa Cruz Biotechnology (Santa Cruz, CA). Anti-phospho-Bcl-2 (Thr-160) antibody was purchased from Cell Signaling Technology (Beverly, MA). CellTiter 96 Aqueous One Solution cell proliferation assay kit was from Promega Corp. (Madison, WI). The Cell Death Detection ELISA ${ }^{\text {PLUS }}$ kit and TUNEL labeling kit were obtained from Roche Diagnostics Corp. (Indianapolis, IN). The Vybrant ${ }^{\mathrm{TM}}$ apoptosis assay kit was from Molecular Probes (Eugene, OR).

Cells and cell culture. The human NSCLC cell lines H460 and A549 were obtained from American Type Culture Collection (ATCC, Manassas, VA). Cell culture medium RPMI-1640, fetal bovine serum (FBS), penicillin-streptomycin-glutamine (x100), and $0.25 \%$ trypsin-EDTA solution were purchased from Invitrogen Corp. (Carlsbad, CA). As described previously (35), the H460 and A549 cell lines were maintained in RPMI-1640 supplemented with $10 \%$ of FBS, $50 \mathrm{IU} / \mathrm{ml}$ penicillin, and $50 \mu \mathrm{g} / \mathrm{ml}$ streptomycin and were grown at $37^{\circ} \mathrm{C}$ in a humidified atmosphere with $5 \% \mathrm{CO}_{2}$.

Anti-proliferation assay. Cell viability and the effects of drugs on cell proliferation in the human lung cancer cells were assessed by an MTT-based colorimetric cell proliferation assay (Promega), following the manufacturer's instructions. In brief, $\mathrm{H} 460$ or A549 cells were distributed at $5 \times 10^{3}$ per well in 96-well plates and grown overnight. The cells were treated with different concentrations of cisplatin $(0,0.25,0.5$, $1.0,2.0,4.0,8.0,16.0,32.0,64.0$ and $128.0 \mu \mathrm{M})$ with or without $30 \mu \mathrm{g} / \mathrm{ml}$ of B-elemene and incubated for 24, 48 or $72 \mathrm{~h}$. At the end of the incubation time, $20 \mu \mathrm{l}$ of CellTiter 96 Aqueous One Solution reagent were added to each well of the 96 -well plate, and the plates were incubated at $37^{\circ} \mathrm{C}$ in an atmosphere of $5 \% \mathrm{CO}_{2}$ for $1-4 \mathrm{~h}$. The optical density at $590 \mathrm{~nm}$ was determined using a 96-well microplate reader (Thermo Labsystems, Chantilly, VA). Proliferation rates were determined by calculating the viable cells in each drug-treated well as a percentage of the viable cells in the control well (no drugs added).

Cell death detection by ELISA. Based on the quantitative sandwich-enzyme-immunoassay principle, the ELISA for cell death detection uses mouse monoclonal antibodies raised against DNA and histones to provide a quantitative in vitro determination of histone-associated DNA fragments (monoand oligo-nucleosomes) in the cytoplasmic fractions of cell lysates. Briefly, H460 cells (1x104/well) were distributed in 
96-well plates and grown overnight. The cells were treated with medium only (untreated), $\beta$-elemene $(30 \mu \mathrm{g} / \mathrm{ml})$, cisplatin $(2$ or $4 \mu \mathrm{M})$, or $\beta$-elemene $(30 \mu \mathrm{g} / \mathrm{ml})+$ cisplatin $(2$ or $4 \mu \mathrm{M})$ for 24 or $48 \mathrm{~h}$. At the end of the incubation time, the cells were harvested and assayed for apoptosis by using a Cell Death Detection ELISA kit, following the manufacturer's instructions.

Quantitation of apoptosis by TUNEL assay. For the terminal deoxynucleotidyltransferase-mediated deoxy-UTP-fluorescein nick end labeling (TUNEL) assay, an Apoptosis Cell Detection System (Roche Molecular Biochemicals, Indianapolis, IN) was used to detect DNA fragmentation as a marker of apoptotic cell death in situ in lung cancer cells treated with cisplatin or B-elemene. In brief, H460 cells were treated with medium only (untreated), B-elemene alone $(30 \mu \mathrm{g} / \mathrm{ml})$, cisplatin alone (2 or $4 \mu \mathrm{M})$, or $\beta$-elemene $(30 \mu \mathrm{g} / \mathrm{ml})+$ cisplatin $(2$ or $4 \mu \mathrm{M})$, then incubated for 24 or $48 \mathrm{~h}$, and harvested. The collected cell pellets were processed into formalin-fixed paraffinembedded cell blocks. Sections of the cell blocks were deparaffinized, washed three times with PBS, and incubated with $50 \mu \mathrm{l}$ of TUNEL reaction mixture containing deoxyUTP-fluorescein (TUNEL label) and terminal deoxynucleotidyltransferase (TUNEL enzyme), in the dark for $60 \mathrm{~min}$ at $37^{\circ} \mathrm{C}$ in a humidified atmosphere. Next, the cells were rinsed three times with $\mathrm{PBS}$, incubated with $50 \mu \mathrm{l}$ of Converter-AP in a humidified atmosphere for $30 \mathrm{~min}$ at $37^{\circ} \mathrm{C}$, rinsed again three times with $\mathrm{PBS}$, and incubated with $50 \mu \mathrm{l}$ of substrate solution in the dark at $25^{\circ} \mathrm{C}$ for a period of time adjusted for optimal staining. Finally, the slides were rinsed three times with PBS and mounted under a glass cover slip for analysis by light microscopy.

Quantitation of apoptosis by annexin $V$ and propidium iodide staining. To quantify apoptosis, H460 cells were stained with annexin $\mathrm{V}$ and propidium iodide (PI) using a Vybrant apoptosis assay kit, following the step-by-step protocol provided by the manufacturer. Briefly, $1 \times 10^{6}$ cells were treated with medium only (untreated), B-elemene alone $(30 \mu \mathrm{g} / \mathrm{ml})$, cisplatin alone $(2$ or $4 \mu \mathrm{M})$, or $\beta$-elemene $(30 \mu \mathrm{g} / \mathrm{ml})+$ cisplatin $(2$ or $4 \mu \mathrm{M})$ for 24 or $48 \mathrm{~h}$. The cells were collected by trypsinization and washed once with cold PBS. The cell pellets were resuspended in $100 \mu 1$ of $1 \mathrm{X}$ annexin binding buffer, $5 \mu \mathrm{l}$ of FITC-annexin V (Component A), and $1 \mu \mathrm{l}$ of $100 \mu \mathrm{g} / \mathrm{ml}$ PI working solution. After incubation on ice for $1 \mathrm{~h}$, the cells were washed once with cold PBS and resuspended in $300 \mu \mathrm{l}$ of $1 \mathrm{X}$ annexin binding buffer. Immediately after staining, the cells were analyzed for apoptosis by flow cytometry.

Caspase activity assays. Caspase activities were assayed using CasPASE ${ }^{\mathrm{TM}}-9,-3,-7$ and -10 assay kits (Geno Technology, St. Louis, MO). In brief, $2 \times 10^{7} \mathrm{H} 460$ cells were treated with medium only (untreated), B-elemene alone $(30 \mu \mathrm{g} / \mathrm{ml})$, cisplatin alone $(2$ or $4 \mu \mathrm{M})$, or B-elemene $(30 \mu \mathrm{g} / \mathrm{ml})+$ cisplatin $(2$ or $4 \mu \mathrm{M})$ and incubated for 24 or $48 \mathrm{~h}$. The cells were collected by trypsinization, washed once with PBS, and lysed by five freeze-thaw cycles in $350 \mu 1$ of lysis buffer. The lysates were centrifuged at 12,000 x $\mathrm{g}$ for $30 \mathrm{~min}$ at $4^{\circ} \mathrm{C}$. The supernatants were collected and used for measuring caspase-9, -3, -7 and -10 activities by an ELISAbased assay according to the manufacturer's instructions. Caspase-3, - 7 and -10 activities were detected using a caspasespecific fluorogenic substrate, DEVD peptide conjugated to 7-amino-4-trifluoromethyl coumarin (AFC). Caspase-9 activity was detected using a caspase-9-specific fluorogenic substrate, LEHD-AFC. Samples were read using a microplate reader at $405 \mathrm{~nm}$.

Western blot analysis. H460 cells were treated with medium only (untreated), B-elemene alone $(30 \mu \mathrm{g} / \mathrm{ml})$, cisplatin alone ( 2 or $4 \mu \mathrm{M})$, or $\beta$-elemene $(30 \mu \mathrm{g} / \mathrm{ml})+$ cisplatin $(2$ or $4 \mu \mathrm{M})$ and incubated for 24 or $48 \mathrm{~h}$, after which the cells were harvested and lysed with $200 \mu 1$ of RIPA lysis buffer [50 mM Tris- $\mathrm{HCl}(\mathrm{pH} 7.4), 1.0 \%$ NP-40, $0.25 \%$ Na-deoxycholate, $150 \mathrm{mM} \mathrm{NaCl}, 1 \mathrm{mM}$ EDTA, $1 \mathrm{mM}$ aprotinin, $1 \mu \mathrm{g} / \mathrm{ml}$ of PMSF, leupeptin and pepstatin]. The amount of protein was quantified using a bicinchoninic acid (BCA) assay. Equal amounts of protein from control and drug-treated cells were boiled for 5 min in Laemmli's buffer and separated by $12 \%$ SDS-PAGE. The resolved proteins were blotted onto nitrocellulose membranes and probed with primary antibodies against caspase-3, caspase-9, Bcl-2, phospho-Bcl-2, Bax, cytochrome $\mathrm{c}$ and poly(ADP-ribose) polymerase (PARP), followed by secondary HRP-conjugated antibodies. In all cases, the blots were stripped using a stripping buffer $[62.5 \mathrm{mM}$ Tris (pH 6.7), 2\% SDS and $90 \mathrm{mM}$ 2-mercaptoethanol] and reprobed with anti-actin antibody as a loading control. Signals were detected by enhanced chemiluminescence.

Detection of released cytochrome $c$. Cytosolic and mitochondrial extracts were prepared using a mitochondria isolation kit (Sigma-Aldrich) according to manufacturer's instructions. In brief, cells were treated with medium only (untreated), ß-elemene alone $(30 \mu \mathrm{g} / \mathrm{ml})$, cisplatin alone (2 or $4 \mu \mathrm{M})$, or $\beta$-elemene $(30 \mu \mathrm{g} / \mathrm{ml})+$ cisplatin $(2$ or $4 \mu \mathrm{M})$ for 24 or $48 \mathrm{~h}$. The cells were collected by centrifugation, washed twice with cold PBS, resuspended in ice-cold buffer A [50 mM HEPES (pH 7.5), $1 \mathrm{M}$ mannitol, $350 \mathrm{mM}$ sucrose, $5 \mathrm{mM}$ EGTA, $10 \mu \mathrm{g} / \mathrm{ml}$ leupeptin and $10 \mu \mathrm{g} / \mathrm{ml}$ aprotinin], and homogenized with a glass homogenizer. Nuclei and intact cells were cleared by centrifugation at $600 \mathrm{x}$ g for $10 \mathrm{~min}$ at $4^{\circ} \mathrm{C}$. The supernatant was centrifuged at $14,000 \mathrm{x} \mathrm{g}$ for $20 \mathrm{~min}$ at $4^{\circ} \mathrm{C}$ to pellet the mitochondrial fraction, and an aliquot of the resulting supernatant was used as the soluble cytosolic fraction. The mitochondrial pellet was washed once and then suspended in buffer A. Equal amounts of protein from the mitochondrial and cytosolic fractions were subjected to Western blot analysis with an anti-cytochrome $\mathrm{c}$ antibody.

Statistical analysis. The quantitative data were analyzed with Student's t-test. All tests were two-sided, and $\mathrm{P}<0.05$ was considered significant.

\section{Results}

$\beta$-Elemene sensitizes NSCLC cells to cisplatin-induced cytotoxicity. Cisplatin is one of the most effective chemotherapeutic drugs for NSCLC, but it has a narrow therapeutic window between efficacy and unacceptable toxicity $(11,12)$. 


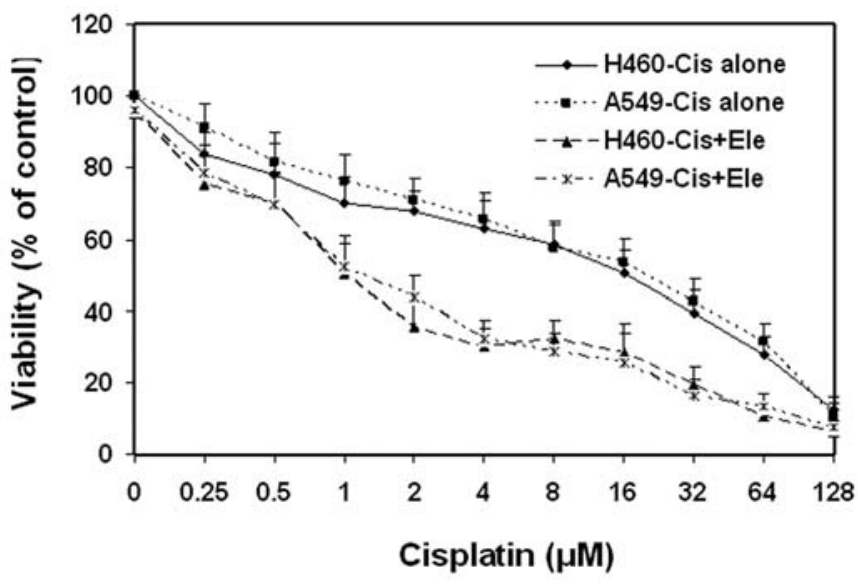

Figure 1. ß-Elemene enhances the inhibitory effect of cisplatin on cell proliferation in human NSCLC cells. H460 or A549 cells $\left(5 \times 10^{3}\right.$ cells per well) were distributed in 96-well plates and treated with different concentrations of cisplatin alone $(0,0.25,0.5,1.0,2.0,4.0,8.0,16.0,32.0$, 64.0 , or $128.0 \mu \mathrm{M})$ or B-elemene $(30 \mu \mathrm{g} / \mathrm{ml})+$ cisplatin $(0,0.25,0.5,1.0$, $2.0,4.0,8.0,16.0,32.0,64.0$, or $128.0 \mu \mathrm{M}$ ) for 24,48 , or $72 \mathrm{~h}$ (data not shown at 24 and $72 \mathrm{~h}$ time points). The ability of the drugs to inhibit cell proliferation was determined by an MTT cell survival assay. Cell viability is expressed as a percentage of control (no drug treatment) cell viability. The results represent the means $\pm \mathrm{SD}$ of at least three independent experiments.

B-Elemene, a new plant-derived anticancer agent, effectively inhibits NSCLC cell proliferation and has low toxicity $(13,14,18)$. We tested whether B-elemene could enhance the cell killing effect of cisplatin, using the $\mathrm{H} 460$ and A549 cell lines as models for human NSCLC. The effect of cisplatin alone or in combination with $B$-elemene on the proliferation of H460 and A549 cells was assessed in vitro by the MTT assay. As shown in Fig. 1, B-elemene at $30 \mu \mathrm{g} / \mathrm{ml}$ remarkably increased the inhibition of cell proliferation by cisplatin in both H460 and A549 NSCLC cells. In H460 cells, cisplatin alone had a half-maximal inhibitory effect on proliferation at concentrations $\left(\mathrm{IC}_{50}\right)$ of 40,16 and $9 \mu \mathrm{M}$ at 24,48 and $72 \mathrm{~h}$, respectively. When combined with $\beta$-elemene, cisplatin had $\mathrm{IC}_{50}$ values of $2.2,1.1$ and $0.8 \mu \mathrm{M}$ at 24,48 and $72 \mathrm{~h}$, respectively. Similarly, in $\mathrm{A} 549$ cells, the $\mathrm{IC}_{50}$ values for cisplatin were 76,34 and $16 \mu \mathrm{M}$ at 24,48 and $72 \mathrm{~h}$, respectively, with cisplatin alone, whereas the $\mathrm{IC}_{50}$ values for cisplatin were $4.5,2.1$ and $1.2 \mu \mathrm{M}$ at 24,48 and $72 \mathrm{~h}$, respectively, when cisplatin was combined with $B$-elemene (Fig. 1; data not shown at 24 and $72 \mathrm{~h}$ ). These data demonstrate that B-elemene strongly enhances the inhibition of cell proliferation by cisplatin in both of the human NSCLC cell lines.

$\beta$-Elemene enhances cisplatin-induced apoptosis in NSCLC cells. The major goal of cancer chemotherapy is to commit tumor cells to apoptosis following exposure to anticancer agents (36), and it is generally believed that the induction of apoptosis is the primary cytotoxic mechanism of cisplatin (37). To determine whether $\beta$-elemene-induced apoptosis accounts for the ability of $\beta$-elemene to increase cisplatininduced inhibition of cell growth and proliferation, we used an ELISA-based assay, TUNEL assay and annexin V/ propidium iodide (PI) staining to quantify apoptotic changes in $\mathrm{H} 460$ cells.

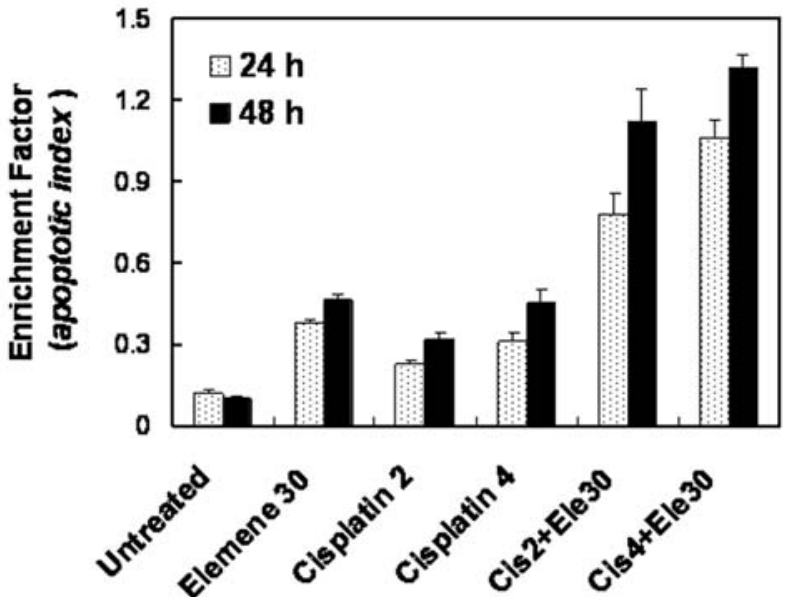

Figure 2. B-Elemene enhances cisplatin-induced apoptosis in human NSCLC cells as measured with an ELISA-based assay. H460 cells were treated with medium only (untreated), B-elemene alone $(30 \mu \mathrm{g} / \mathrm{ml})$, cisplatin alone (2 or $4 \mu \mathrm{M})$, or B-elemene $(30 \mu \mathrm{g} / \mathrm{ml})+$ cisplatin $(2$ or $4 \mu \mathrm{M})$ for 24 or $48 \mathrm{~h}$. Cellular apoptosis was determined with an ELISA-based cell death detection kit. The results are expressed as the means $\pm \mathrm{SD}$ of three independent experiments. $\mathrm{P}<0.05$ for the cisplatin $+\beta$-elemene groups vs. cisplatin alone or B-elemene alone.

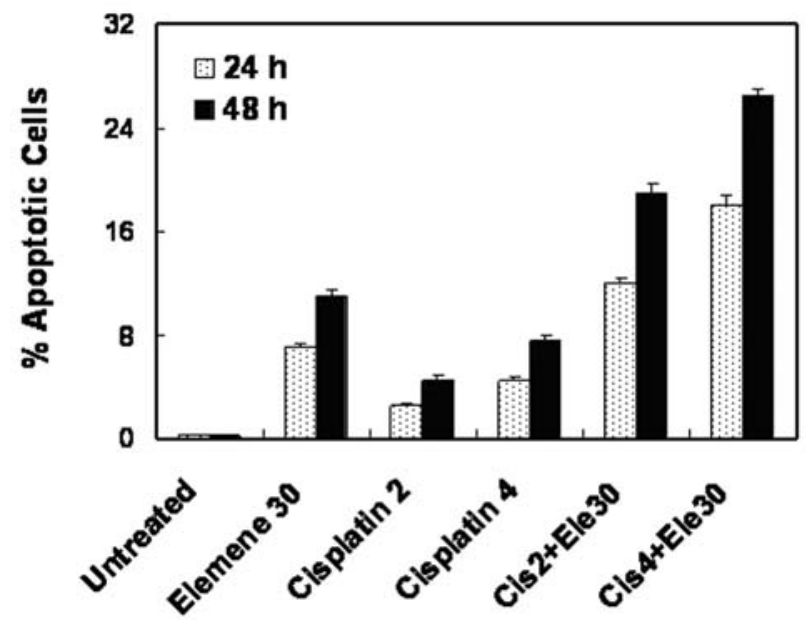

Figure 3. B-Elemene increases cisplatin-induced apoptosis in human NSCLC cells as assessed by TUNEL assay. $\mathrm{H} 460$ cells were treated with medium only (untreated), B-elemene alone ( $30 \mu \mathrm{g} / \mathrm{ml})$, cisplatin alone ( 2 or $4 \mu \mathrm{M})$, or B-elemene $(30 \mu \mathrm{g} / \mathrm{ml})+$ cisplatin $(2$ or $4 \mu \mathrm{M})$ for 24 or $48 \mathrm{~h}$. At the end of the treatment period, the cells were collected, processed into paraffinembedded cell blocks, and sectioned at 5 microns. Cell apoptosis was determined with a TUNEL assay kit. Apoptotic cells were counted under a light microscope and reported as a percentage of the total cells presented for evaluation. The results are expressed as the means $\pm \mathrm{SD}$ of three independent experiments. B-Elemene remarkably increased cisplatin-induced DNA fragmentation in a dose-dependent manner, which is consistent with apoptotic cell death in $\mathrm{H} 460$ cells. $\mathrm{P}<0.05$ for the cisplatin $+B$-elemene groups vs. cisplatin alone or ß-elemene alone.

DNA fragmentation is a marker and characteristic event of apoptosis (38). An ELISA-based assay performed with mouse monoclonal antibodies directed against DNA and histones provides a quantitative in vitro determination of histone-associated DNA fragments $(38,39)$. Fig. 2 shows the results of an ELISA-based assay of H460 cells exposed to 
B-elemene or cisplatin alone or to the combination of both agents for 24 or $48 \mathrm{~h}$. The number of apoptotic cells clearly increased $(\mathrm{P}<0.05)$ after all three treatments, but the combination treatment produced a significantly greater increase in apoptosis than either agent acting alone.

ß-Elemene-enhanced cisplatin-induced apoptosis was further confirmed by TUNEL assay, a classic technique used to detect apoptotic cells in culture $(39,40)$. As seen in Fig. 3, very few apoptotic cells were detected among the untreated control cells. However, apoptosis was increased in H460 cells by $ß$-elemene or cisplatin alone, and the increase was significantly greater in $\mathrm{H} 460$ cells treated with ß-elemene and cisplatin in combination. Quantitative analysis of the sections revealed that $\beta$-elemene increased cisplatin-induced apoptosis in $\mathrm{H} 460$ cells at 24 and $48 \mathrm{~h}$ in a dose-dependent manner (Fig. 3).

Phosphatidylserine translocation occurs early in apoptosis, when cell membranes are still intact. Annexin V binds to phosphatidylserine with high affinity, and flow cytometric analysis using FITC-labeled annexin V is commonly used to quantitatively measure early apoptosis $(41,42)$. The ability of B-elemene to increase cisplatin-induced apoptosis was examined by annexin V/PI staining using a Vybrant apoptosis assay kit. The results show that $\beta$-elemene significantly enhanced cisplatin-induced apoptosis in H460 cells in a dosedependent fashion (Fig. 4). The findings from all three independent assays suggest that $B$-elemene sensitizes NSCLC cells to cisplatin by triggering apoptosis.

\section{$\beta$-Elemene augments cisplatin-induced activation of caspases in NSCLC cells. Caspase proteases are the ultimate effectors of apoptosis. The activation of initiator pro-caspase- 9 depends primarily on a mitochondrial signaling pathway involving members of the Bcl-2 family and is generally accepted as the major pathway of anticancer drug-induced apoptosis (43-46). To investigate whether the action of B- elemene on cisplatin-induced apoptosis occurs via enhanced caspase activity in an intrinsic apoptosis pathway, we assessed the activities of caspase-3, -7, -9 and -10 in an ELISA-based assay. Fig. 5 shows that the activities of caspase-9 (Fig. 5A) and caspase-3, -7, -10 (Fig. 5B) were clearly increased following the treatment of $\mathrm{H} 460$ cells with $\beta$-elemene or cisplatin alone. Both activities were further increased significantly with the combination treatment of cisplatin and B-elemene for 24 and $48 \mathrm{~h}$, compared with cisplatin alone $(\mathrm{P}<0.05)$. These data suggest that $\beta$-elemene promotes cisplatin-induced apoptosis in H460 cells via a caspase-9- dependent apoptosis pathway.}

$\beta$-Elemene increases the cisplatin-induced levels of apoptosis regulatory proteins and their activation in NSCLC cells. To further investigate how $ß$-elemene enhances cisplatininduced apoptosis, we looked at changes in the levels of several key apoptosis-related proteins, including Bcl-2, Bax, cytochrome c, XIAP, caspase-9, caspase-3 and poly(ADPribose) polymerase (PARP). Bcl-2 family members such as Bcl-2 and Bax play critical roles in the regulation of cytochrome c release from the mitochondria into the cytosol $(22-25,47)$, which initiates caspase activation and apoptotic cell death $(27,48)$. XIAP is an important intrinsic regulator of

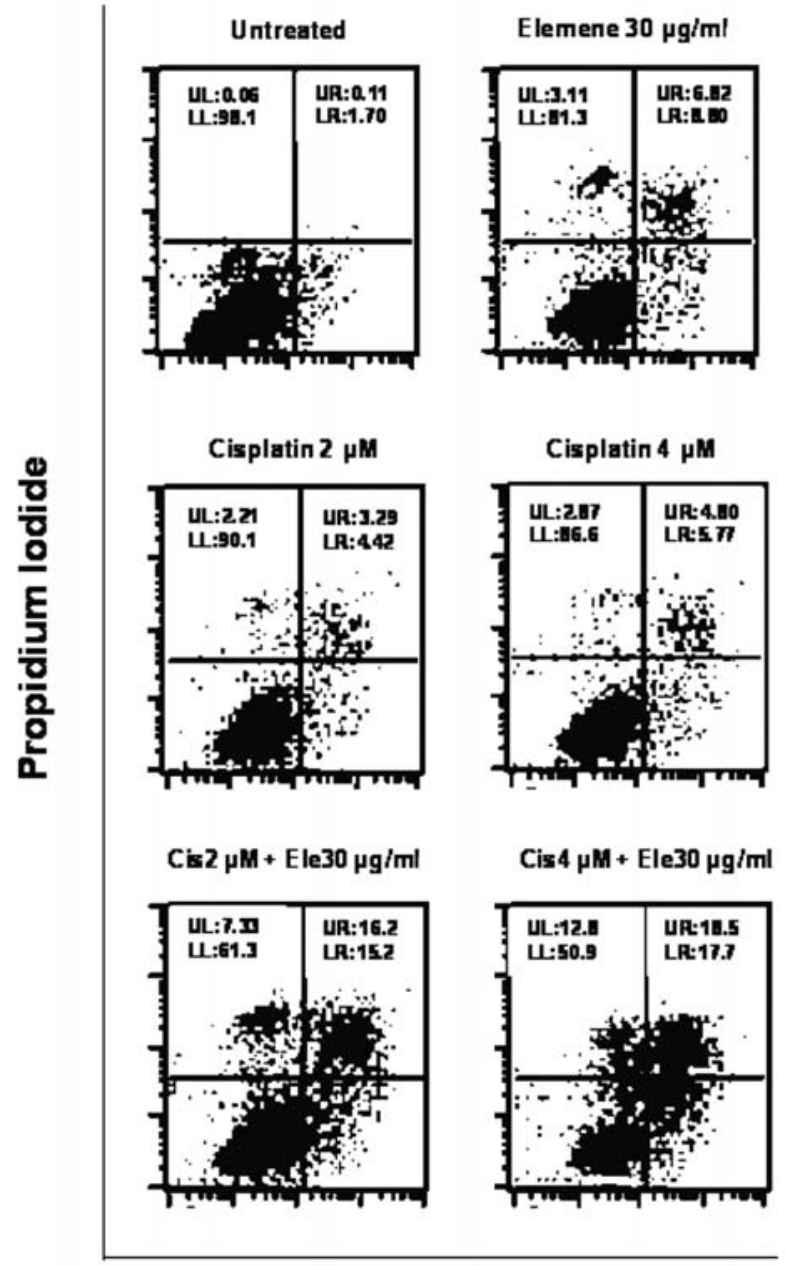

Annexin V - FITC

Figure 4. B-Elemene augments cisplatin-induced apoptosis in human NSCLC cells as assayed by annexin V staining. H460 cells were exposed to medium only (untreated), B-elemene alone $(30 \mu \mathrm{g} / \mathrm{ml})$, cisplatin alone (2 or $4 \mu \mathrm{M})$, or $\beta$-elemene $(30 \mu \mathrm{g} / \mathrm{ml})+$ cisplatin $(2$ or $4 \mu \mathrm{M})$ for $48 \mathrm{~h}$. The cells were harvested and were stained using a Vybrant apoptosis assay kit. Apoptosis was determined by flow cytometry of the cells labeled with FITC-annexin V and propidium iodide (PI). Cytograms of FITC-annexin V binding (abscissa) vs. PI uptake (ordinate) show three distinct populations: (i) viable cells (low FITC and low PI signals) in gate LL; (ii) early apoptotic cells (high FITC and low PI signals) in gate LR and (iii) cells that have lost membrane integrity as a result of late apoptosis (high FITC and high PI signals) in gate UR. The percentages of apoptotic cells (gate LR and gate UR) are indicated on each cytogram. A representative of three separate experiments is shown.

the caspase cascade $(32,33)$, and caspase- 9 is a marker for the intrinsic apoptosis pathway $(43,44,49)$. PARP is an early marker of chemotherapy-induced apoptosis $(30,31)$.

H460 cells were treated with ß-elemene or cisplatin alone or with a combination of both agents for 24 or $48 \mathrm{~h}$, and the levels of Bcl-2, phosphorylated Bcl-2, Bax, cytochrome c, XIAP, PARP, pro-caspase-9, pro-caspase-3, and the cleaved enzymes caspase- 9 and caspase- 3 were analyzed by Western blotting. As shown in Figs. 6 and 7, $\beta$-elemene significantly augmented the cisplatin-induced reduction in the levels of Bcl-2 and XIAP and the cisplatin-induced increases in the levels of Bax, phosphorylated Bcl-2, cytosolic cytochrome c, 

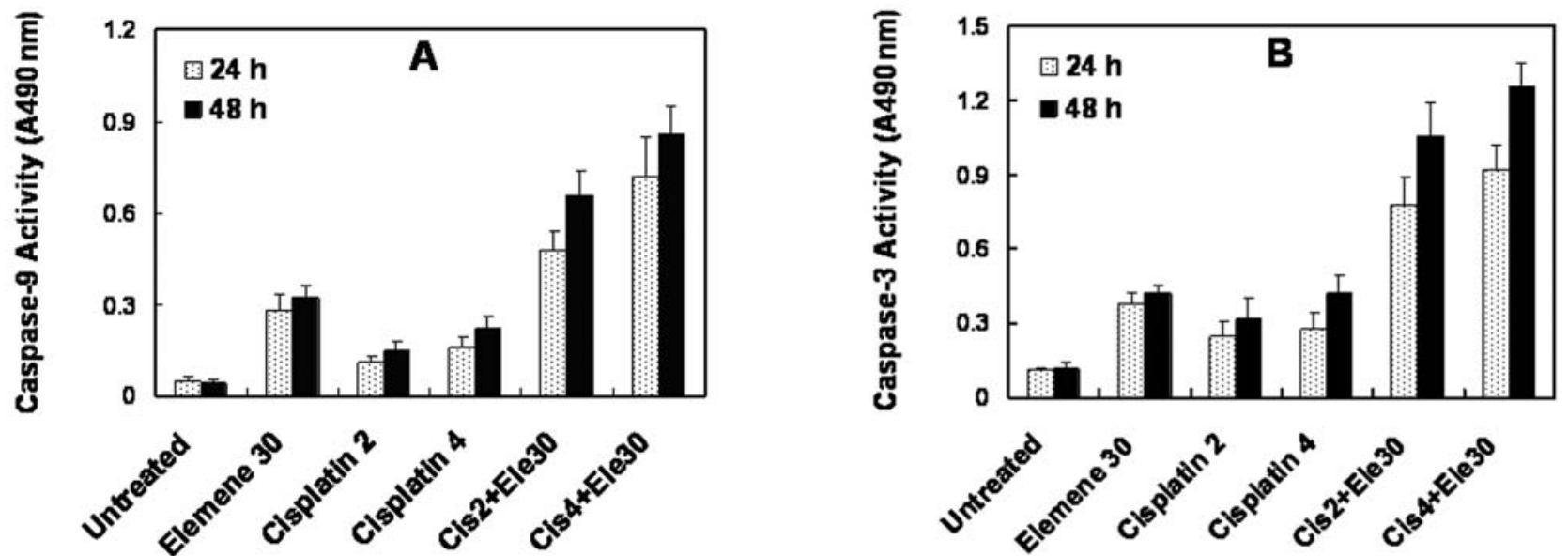

Figure 5. B-Elemene and cisplatin induce increases in caspase activity in human NSCLC cells. H460 cells were treated with medium only (untreated), B-elemene alone $(30 \mu \mathrm{g} / \mathrm{ml})$, cisplatin alone $(2$ or $4 \mu \mathrm{M})$, or B-elemene $(30 \mu \mathrm{g} / \mathrm{ml})+$ cisplatin $(2$ or $4 \mu \mathrm{M})$ for 24 or $48 \mathrm{~h}$. Caspase-9 (A) and caspase-3, -7 and -10 (B) activities were measured with an ELISA-based assay. The results are expressed as the means \pm SD of three independent experiments. $\mathrm{P}<0.05$ for the cisplatin $+\beta$ elemene groups vs. cisplatin alone or $\beta$-elemene alone.

$\begin{array}{lllllll}0 & 0 & 2 & 4 & 2 & 4 & \text { Cisplatin }(\mu \mathrm{M}) \\ 0 & 30 & 0 & 0 & 30 & 30 & \beta \text {-Elemene }(\mu \mathrm{g} / \mathrm{ml})\end{array}$
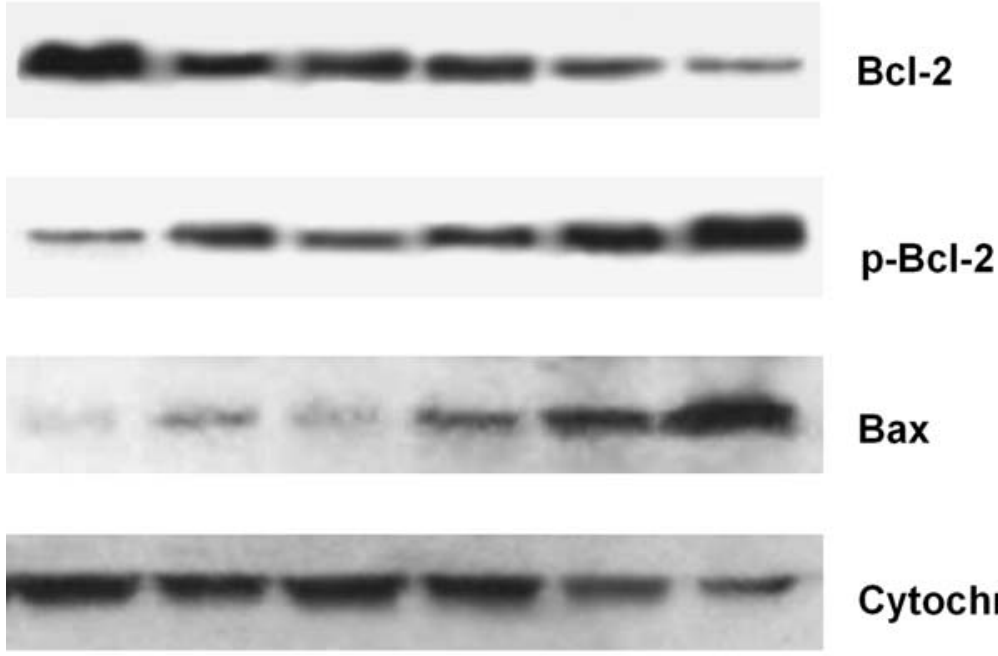

Bax

\section{Cytochrome $C(\mathrm{M})$}

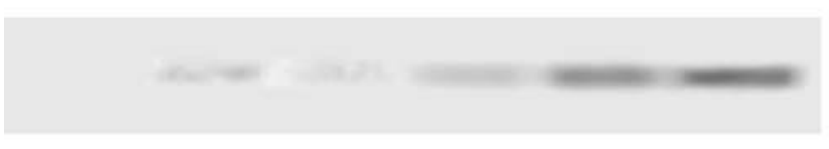

\section{Cytochrome C (C)}

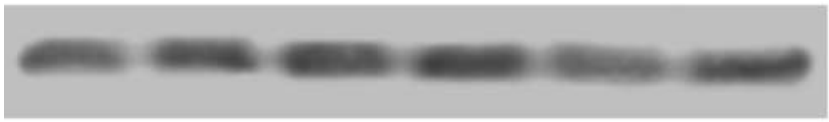

\section{$\beta$-Actin}

Figure 6. B-Elemene increases the effects of cisplatin on the levels of apoptosis regulatory proteins in human NSCLC cells. H460 cells were exposed to medium only (untreated), B-elemene alone ( $30 \mu \mathrm{g} / \mathrm{ml})$, cisplatin alone $(2$ or $4 \mu \mathrm{M})$, or B-elemene $(30 \mu \mathrm{g} / \mathrm{ml})+$ cisplatin $(2$ or $4 \mu \mathrm{M})$ for $48 \mathrm{~h}$. A total of $50 \mu \mathrm{g}$ of cell extract protein isolated from the drug-treated $\mathrm{H} 460$ cells was subjected to Tris-glycine gel electrophoresis. The proteins were transferred to a membrane and immunoblotted with antibodies against Bcl-2, phospho-Bcl-2, Bax and cytochrome $\mathrm{c}$. B-actin was used as a loading control. The data presented are representative of those from three separate experiments. Cytochrome c (M), mitochondrial cytochrome c; cytochrome c (C), cytosolic cytochrome c.

PARP, and cleaved caspase- 9 and -3 . These results demonstrate that $\beta$-elemene augments cisplatin-induced apoptosis at the molecular level, possibly acting through an intrinsic apoptosis pathway. 

$0 \quad 0$
2
4
2
4
Cisplatin $(\mu \mathrm{M})$
0
30
0
$0 \quad 30$
30
$\beta$-Elemene $(\mu \mathrm{g} / \mathrm{ml})$

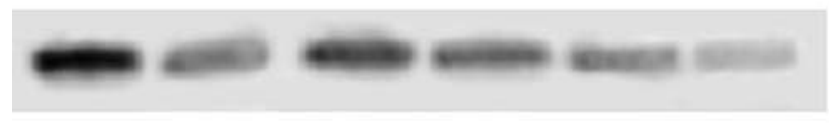

XIAP

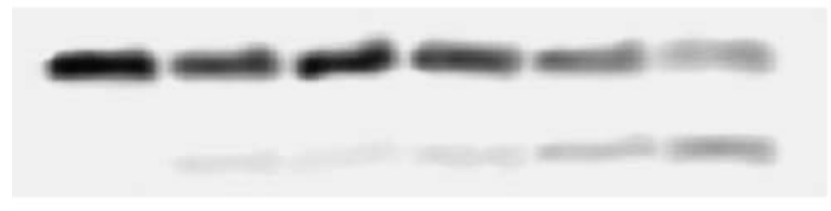

\section{Caspase-9}

Cleaved caspase-9

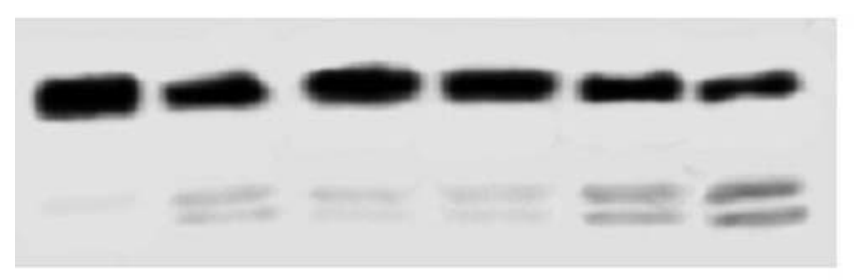

\section{Caspase-3}

Cleaved caspase-3

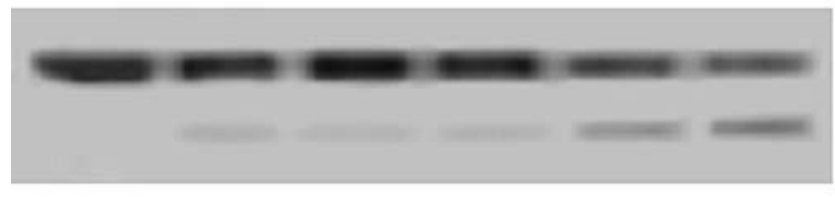

PARP

Cleaved PARP

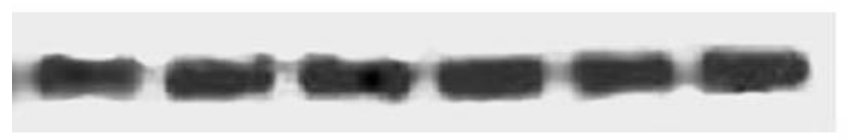

$\beta$-Actin

Figure 7. B-Elemene augments the effects of cisplatin on the levels and activities of apoptosis regulatory proteins in human NSCLC cells. H460 cells were exposed to medium only (untreated), $\beta$-elemene alone $(30 \mu \mathrm{g} / \mathrm{ml})$, cisplatin alone $(2$ or $4 \mu \mathrm{M})$, or $\beta$-elemene $(30 \mu \mathrm{g} / \mathrm{ml})+\operatorname{cisplatin}(2 \mathrm{or} 4 \mu \mathrm{M})$ for $48 \mathrm{~h}$. A total of $50 \mu \mathrm{g}$ cell extract protein isolated from the drug-treated $\mathrm{H} 460$ cells was subjected to Tris-glycine gel electrophoresis. The proteins were transferred to a membrane and immunoblotted with antibodies against XIAP, caspase-9, caspase- 3 and PARP. $\beta$-actin was used as a loading control. The data presented are representative of those from three independent experiments.

\section{Discussion}

Cisplatin has been a major cancer chemotherapeutic agent for more than two decades, and cisplatin-based combination treatments remain the first-line chemotherapy for NSCLC. However, the currently available cisplatin-based chemotherapy exhibits a narrow therapeutic window between efficacy and unacceptable toxicity $(5,7)$. Thus, the development of lowtoxicity chemotherapy treatments for NSCLC is a priority. ß-Elemene, an extract from the traditional Chinese medicinal herb Rhizoma zedoariae, is a promising novel anticancer agent with a broad spectrum of antitumor effects (13-15). It displays low toxicity, with no observable liver, kidney, or bone marrow toxicities, and is well tolerated by cancer patients (13-15). Previously, we showed that ß-elemene successfully inhibited NSCLC cell proliferation (18). In the present study, we investigated whether $\beta$-elemene can augment the cell killing effect of cisplatin and explored B-elemene's mechanism of action.
Here, we show that $\beta$-elemene significantly enhanced the inhibitory effect of cisplatin on the growth of human NSCLC cells in vitro. Furthermore, this effect of $B$-elemene on cisplatin activity occurred through the induction of apoptosis in NSCLC cells, which is supported by our findings of increased Bax and phospho-Bcl-2 levels and decreased Bcl-2 and XIAP levels in cells exposed to the combination of Belemene and cisplatin compared with cells treated with each agent alone. Finally, ß-elemene augmented cisplatin-induced increases in caspase-3, $-7,-9$ and -10 activities and resulted in significantly elevated levels of cleaved caspase-3, -9 and PARP in NSCLC cells.

To analyze the biochemical mechanism by which $\beta$ elemene markedly enhanced cisplatin-induced inhibition of NSCLC cell proliferation, we examined the abilities of cisplatin and $\beta$-elemene, alone and in combination, to induce cell death in H460 cells. We found that the apoptotic index with the combination treatment was significantly higher than that with either agent alone (Fig. 2). Furthermore, a TUNEL 


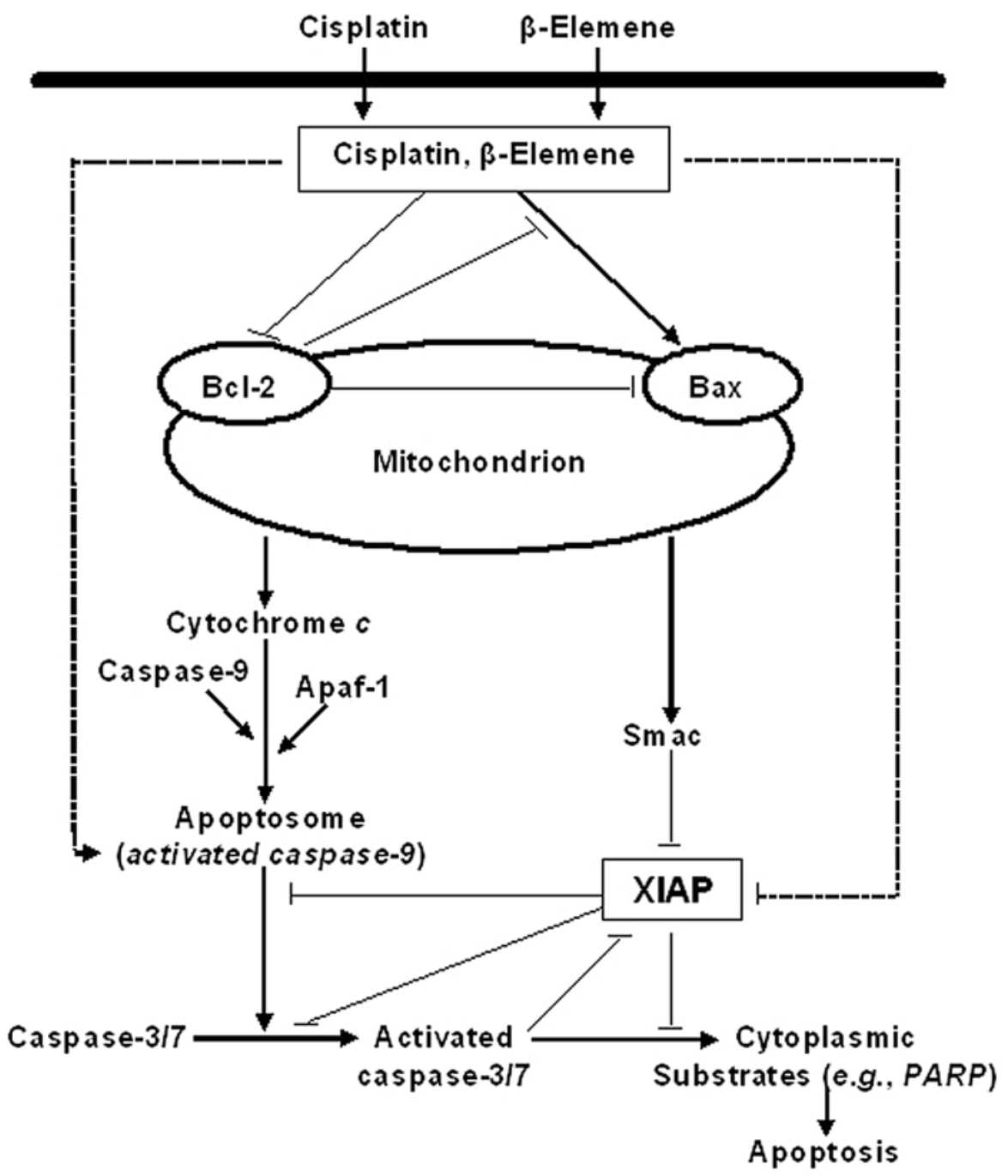

Figure 8. Proposed molecular mechanism for the action of B-elemene on cisplatin chemosensitivity in human lung carcinoma cells. This schematic illustrates a possible mechanism by which B-elemene acts via a mitochondria-mediated apoptosis pathway to significantly enhance the effects of cisplatin on NSCLC cells. In brief, B-elemene enhances cisplatin sensitivity in human lung carcinoma cells by activation of Bax and inhibition of Bcl-2 and XIAP, which in turn activate the downstream apoptotic pathway leading to released cytochrome $\mathrm{c}$ and increased caspase activity, respectively, and both confer sensitization of resistant lung cancer cells to the chemotherapeutic agent cisplatin. See text for details.

assay demonstrated that cisplatin and B-elemene acted synergistically to induce apoptosis in H460 cells (Fig. 3), and annexin V/PI staining further confirmed that $\beta$-elemene significantly enhanced cisplatin-induced apoptosis, with concentration dependence (Fig. 4). Considerable evidence over the past decades has indicated that cisplatin triggers cancer cell death via the induction of apoptosis (50-52). Therefore, $\beta$-elemene may promote the effect of cisplatin on NSCLC cell proliferation, at least in part, by augmenting the ability of cisplatin to initiate apoptosis.

The molecular mechanisms of the interactions between $B$ elemene and cisplatin are complex. In the present study, Belemene significantly promoted cisplatin-induced apoptosis and acted synergistically with cisplatin to increase the activities of caspase-9, -3, -7 and-10 (Fig. 5) and to significantly enhance cisplatin-induced increases in the levels of cleaved caspase-9, -3, and PARP (Fig. 7). These findings indicate that $\beta$-elemene promotes cisplatin's inhibition of cell proliferation via the caspase- 9 apoptosis pathway, in agreement with previous studies showing that the caspase-9- dependent mitochondria-mediated apoptosis pathway is the primary pathway of antitumor agent-induced apoptosis (43-46). Moreover, $\beta$-elemene enhanced the cisplatininduced reductions of $\mathrm{Bcl}-2$ and XIAP, and promoted the cisplatin-induced increases of Bax, phosphorylated Bcl-2, and cytochrome c release (Fig. 6). Bcl-2 family members regulate the release of cytochrome $\mathrm{c}$ from mitochondria, which subsequently activates caspase-9 and $-3(24,25,47)$, and XIAP is an important intrinsic regulator of the caspase cascade $(32,33)$. Thus, $\beta$-elemene appears to enhance cisplatininduced inhibition of NSCLC cell growth via the intrinsic apoptosis pathway involving Bcl-2 family proteins and caspase-9.

In addition to the mitochondrial apoptosis signal transduction pathway, cisplatin also activates caspase-8 (53), an important marker of the death receptor-mediated apoptosis pathway (54). Therefore, it is likely that caspase- 8 activation or death receptor signaling also occurs in B-elemene-treated NSCLC cells, possibly through the inhibition of cellular protease caspase- 8 inhibitory protein (55). Furthermore, 
there may be cross-talk between the mitochondrial and death receptor pathways through the pro-apoptotic protein tBid (56).

Combining our results with previously reported findings, we propose a possible mechanism, shown in Fig. 8, by which $ß$-elemene acts via a mitochondria-mediated apoptosis pathway to significantly enhance cisplatin-inhibited NSCLC cell proliferation. First, $\beta$-elemene acts synergistically with cisplatin to decrease $\mathrm{Bcl}-2$ expression and increase Bax expression. Bax then induces a mitochondrial permeability transition, which allows the release of cytochrome $\mathrm{c}$ from the mitochondria into the cytosol. In the cytosol, the released cytochrome $\mathrm{c}$ forms an apoptosome complex with Apaf-1 and caspase-9, leading to the cleavage and activation of caspase-9. Activated caspase- 9 in turn activates downstream caspases such as caspase- 3 and caspase-7. This cascade results in the cleavage of cytoplasmic substrates such as PARP, which are directly responsible for the morphological and biochemical changes in apoptotic cell death. Concurrently, the effect of the apoptosis inhibitor protein XIAP is reduced by $ß$-elemene directly, by Smac released from the mitochondria, and by activated caspase- 3 and -7 , thereby diminishing the inhibition of caspase- $9,-3$ and -7 activities and promoting apoptosis.

In summary, we have described a natural, plant-derived antitumor agent, $\beta$-elemene, that potentiates the anticancer activity of the cytotoxic drug cisplatin in human NSCLC cells. Compared with cisplatin treatment alone, the combination of cisplatin and $\beta$-elemene produced a synergistic effect on apoptosis in NSCLC cells, and this enhancement was linked to the caspase-9 apoptosis pathway. Furthermore, the induction of apoptosis by $ß$-elemene and cisplatin was mediated by regulation of the levels and activities of apoptosis regulatory components in these cells. This study furnishes further insights into the mechanisms underlying the synergistic effect of $\beta$-elemene and cisplatin on cytotoxicity in human carcinoma cells. Additional investigations are required to elucidate whether B-elemene-enhanced sensitivity to cisplatin also occurs through the regulation of cell cycle control in chemoresistant lung tumor cells. Our data provide a scientific basis for developing the combination of $\beta$ elemene and cisplatin as a potentially effective chemotherapy regimen for the treatment of patients with resistant lung cancer and suggest that further preclinical exploration is warranted.

\section{Acknowledgements}

We thank Dr Cynthia Cunningham for technical assistance during the FACS measurements. This study was partly supported by grants from the National Institutes of Health (No. P20RR16440-010003 to Q.Q.L.) and Long Range International Ltd USA, Inc. (to Q.Q.L.).

\section{References}

1. Jemal A, Tiwari RC, Murray T, Ghafoor A, Samuels A, Ward E, Feuer EJ and Thun MJ: Cancer statistics, 2004. CA Cancer J Clin 54: 8-29, 2004

2. Beadsmoore CJ and Screaton NJ: Classification, staging and prognosis of lung cancer. Eur J Radiol 45: 8-17, 2003.
3. Cortes-Funes H: New treatment approaches for lung cancer and impact on survival. Semin Oncol 29: S26-S29, 2002.

4. Bonomi P, Kim K, Fairclough D, Cella D, Kugler J, Rowinsky E, Jiroutek M and Johnson D: Comparison of survival and quality of life in advanced non-small-cell lung cancer patients treated with two dose levels of paclitaxel combined with cisplatin versus etoposide with cisplatin: results of an Eastern Cooperative Oncology Group trial. J Clin Oncol 18: 623-631, 2000.

5. Ramalingam S and Belani CP: State-of-the-art chemotherapy for advanced non-small cell lung cancer. Semin Oncol 31: S68S74, 2004.

6. Loehrer PJ and Einhorn LH: Drugs five years later, cisplatin. Ann Intern Med 100: 704-713, 1984.

7. Johnson DH: Evolution of cisplatin-based chemotherapy in nonsmall cell lung cancer: a historical perspective and the eastern cooperative oncology group experience. Chest 117: S133-S137, 2000.

8. Wang G, Reed E and Li QQ: Molecular basis of cellular response to cisplatin chemotherapy in non-small cell lung cancer. Oncol Rep 12: 955-965, 2004.

9. Fossella FV, Lynch T and Shepherd FA: Second line chemotherapy for NSCLC: establishing a gold standard. Lung Cancer 38: S5-S12, 2002.

10. Kelland LR: New platinum antitumor complexes. Crit Rev Oncol Hematol 15: 191-219, 1993.

11. Gridelli C, Rossi A and Maione P: Treatment of non-small cell lung cancer: state of the art and development of new biologic agents. Oncogene 22: 6629-6638, 2003

12. Rom WN, Hay JG, Lee TC, Jiang Y and Tchou-Wong KM: Molecular and genetic aspects of lung cancer. Am J Respir Crit Care Med 161: 1355-1367, 2000.

13. Qian J and Qin S: Pharmacological and clinical studies of elemene, a new anticancer drug. Chin Clin Cancer 26: 1-3, 1999.

14. Zheng S, Yang H, Zhang S, Wang X, Yu L, Lu J and Li J: Initial study on naturally occurring products from traditional Chinese herbs and vegetables for chemoprevention. J Cell Biochem 27: S106-S112, 1997.

15. Yuan J, Gu ZL, Chou WH and Kwok CY: Elemene induces apoptosis and regulates expression of bcl-2 protein in human leukemia K562 cells. Zhongguo Yao Li Xue Bao 20: 103-106, 1999.

16. Zhou H, Shen J, Hou J, Qiu Y and Luo Q: Experimental study on apoptosis induced by elemene in glioma cells. Ai Zheng 22: 959-963, 2003.

17. Zou L, Liu W and Yu L: B-Elemene induces apoptosis of K562 leukemia cells. Zhonghua Zhong Liu Za Zhi 23: 196-198, 2001.

18. Wang G, Li X, Huang F, Zhao J, Ding H, Cunningham C, Coad J, Flynn D, Reed E and Li QQ: Antitumor effect of ß-elemene in non-small cell lung cancer cells is mediated via induction of cell cycle arrest and apoptotic cell death. Cell Mol Life Sci 62: 881-893, 2005 .

19. Wang B, Guo J, Di J and Shi Q: The experimental study of association between elemene and tumor multidrug-resistance. Chin Clin Cancer 26: 10-13, 1999.

20. Green DR and Reed JC: Mitochondria and apoptosis. Science 281: 1309-1312, 1998

21. Desagher S and Martinou JC: Mitochondria as the central control point of apoptosis. Trends Cell Biol 10: 369-377, 2000.

22. Wei MC, Zong WX, Cheng EH, Lindsten T, Panoutsakopoulou V, Ross AJ, Roth KA, MacGregor GR, Thompson CB and Korsmeyer SJ: Proapoptotic BAX and BAK: a requisite gateway to mitochondrial dysfunction and death. Science 292: 727-730, 2001.

23. Harris $\mathrm{MH}$ and Thompson CB: The role of the Bcl-2 family in the regulation of outer mitochondrial membrane permeability. Cell Death Differ 7: 1182-1191, 2000.

24. Gross A, McDonnell J and Korsmeyer S: BCL-2 family members and the mitochondria in apoptosis. Genes Dev 13: 1899-1911, 1999.

25. Kluck R, Bossy-Wetzel E, Green D and Newmeyer D: The release of cytochrome $\mathrm{c}$ from mitochondria: a primary site for Bcl-2 regulation of apoptosis. Science 275: 1132-1136, 1997.

26. Pastorino JG, Chen ST, Tafani M, Snyder JW and Farber JL: The overexpression of Bax produces cell death upon induction of the mitochondrial permeability transition. J Biol Chem 273: 7770-7775, 1998. 
27. Li P, Nijhawan D, Budihardjo I, Srinivasula S, Ahmad M, Alnemri E and Wang X: Cytochrome c and dATP-dependent formation of Apaf-1/caspase-9 complex initiates an apoptotic protease cascade. Cell 91: 479-489, 1997.

28. Zou H, Li Y, Liu X and Wang X: An APAF-1.cytochrome c multimeric complex is a functional apoptosome that activates procaspase-9. J Biol Chem 274: 11549-11556, 1999.

29. Kroemer G and Reed JC: Mitochondrial control of cell death Nat Med 6: 513-519, 2000.

30. Kaufmann SH, Desnoyers S, Ottaviano Y, Davidson NE and Poirier GG: Specific proteolytic cleavage of poly(ADP-ribose) polymerase: an early marker of chemotherapy-induced apoptosis. Cancer Res 53: 3976-3985, 1993.

31. Duriez PJ and Shah GM: Cleavage of poly(ADP-ribose) polymerase: a sensitive parameter to study cell death. Biochem Cell Biol 75: 337-349, 1997.

32. Deveraux QL, Leo E, Stennicke HR, Welsh K, Salvesen GS and Reed JC: Cleavage of human inhibitor of apoptosis protein XIAP results in fragments with distinct specificities for caspases. EMBO J 18: 5242-5251, 1999.

33. Srinivasula SM, Hegde R, Saleh A, Datta P, Shiozaki E, Chai J, Lee RA, Robbins PD, Fernandes-Alnemri T, Shi Y and Alnemri ES: A conserved XIAP-interaction motif in caspase-9 and Smac/DIABLO regulates caspase activity and apoptosis. Nature 410: 112-116, 2001

34. Maier JK, Lahoua Z, Gendron NH, Fetni R, Johnston A, Davoodi J, Rasper D, Roy S, Slack RS, Nicholson DW and MacKenzie AE: The neuronal apoptosis inhibitory protein is a direct inhibitor of caspases 3 and 7. J Neurosci 22: 2035-2043, 2002.

35. Wang H, Quan T, He T, Franke T, Voorhees J and Fisher G: Epidermal growth factor receptor-dependent, NF- $\kappa \mathrm{B}-$ independent activation of the phosphatidylinositol 3-kinase/Akt pathway inhibits ultraviolet irradiation-induced caspases-3, -8, and -9 in human keratinocytes. J Biol Chem 278: 45737-45745, 2003.

36. Fisher D: Apoptosis in cancer therapy: crossing the threshold. Cell 78: 539-542, 1994

37. Gonzalez VM, Fuertes MA, Alonso C and Perez JM: Is cisplatin-induced cell death always produced by apoptosis? Mol Pharmacol 59: 657-663, 2001

38. Kim H, Ingermann A, Tsubaki J, Twigg S, Walker G and Oh Y: Insulin-like growth factor-binding protein 3 induces caspasedependent apoptosis through a death receptor-mediated pathway in MCF-7 human breast cancer cells. Cancer Res 64: 2229-2237, 2004.

39. Negoescu A, Lorimier P, Labat-Moleur F, Drouet C, Robert C, Guillermet C, Brambilla C and Brambilla E: In situ apoptotic cell labeling by the TUNEL method: improvement and evaluation on cell preparations. J Histochem Cytochem 44: 959-968, 1996

40. Cryns V and Yuan J: Proteases to die for. Genes Dev 12: 1551-1570, 1998.
41. Homburg C, de Haas M, von dem Borne A, Verhoeven A, Reutelingsperger C and Roos D: Human neutrophils lose their surface Fc gamma RIII and acquire annexin V binding sites during apoptosis in vitro. Blood 85: 532-540, 1995.

42. Koopman G, Reutelingsperger C, Kuijten G, Keehnen R, Pals S and van Oers M: Annexin V for flow cytometric detection of phosphatidylserine expression on B cells undergoing apoptosis. Blood 84: 1415-1420, 1994.

43. Thornberry $\mathrm{N}$ and Lazebnik Y: Caspases: enemies within. Science 281: 1312-1316, 1998.

44. Porter AG and Janicke RU: Emerging roles of caspase-3 in apoptosis. Cell Death Differ 6: 99-104, 1999.

45. Adams JM and Cory S: The Bcl-2 protein family: arbiters of cell survival. Science 281: 1322-1326, 1998.

46. Johnstone R, Ruefli A and Lowe S: Apoptosis: a link between cancer genetics and chemotherapy. Cell 108: 153-164, 2002.

47. Kroemer G: The proto-oncogene Bcl-2 and its role in regulating apoptosis. Nat Med 3: 614-620, 1997.

48. Liu X, Kim C, Yang J, Jemmerson R and Wang X: Induction of apoptotic program in cell-free extracts: requirement for dATP and cytochrome c. Cell 86: 147-157, 1996.

49. Earnshaw W, Martins L and Kaufmann S: Mammalian caspases: structure, activation, substrates, and functions during apoptosis. Annu Rev Biochem 68: 383-424, 1999.

50. Sorenson CM, Barry MA and Eastman A: Analysis of events associated with cell cycle arrest at $\mathrm{G} 2$ phase and cell death induced by cisplatin. J Natl Cancer Inst 82: 749-755, 1990.

51. Wang X, Martindale JL and Holbrook NJ: Requirement for ERK activation in cisplatin-induced apoptosis. J Biol Chem 275: 39435-39443, 2000.

52. Del Bello B, Valentini MA, Zunino F, Comporti M and Maellaro E: Cleavage of Bcl-2 in oxidant- and cisplatin-induced apoptosis of human melanoma cells. Oncogene 20: 4591-4595, 2001.

53. Fukazawa T, Walter B and Owen-Schaub LB: Adenoviral Bid overexpression induces caspase-dependent cleavage of truncated Bid and p53-independent apoptosis in human non-small cell lung cancers. J Biol Chem 278: 25428-25434, 2003.

54. Walczak $\mathrm{H}$ and Haas TL: Biochemical analysis of the native TRAIL death-inducing signaling complex. Methods Mol Biol 414: 221-239, 2008.

55. Frese S, Brunner T, Gugger M, Uduehi A and Schmid RA: Enhancement of Apo2L/TRAIL (tumor necrosis factor-related apoptosis-inducing ligand)-induced apoptosis in non-small cell lung cancer cell lines by chemotherapeutic agents without correlation to the expression level of cellular protease caspase- 8 inhibitory protein. J Thorac Cardiovasc Surg 123: 168-174, 2002.

56. Lagadec C, Adriaenssens E, Toillon RA, Chopin V, Romon R, van Coppenolle F, Hondermarck $\mathrm{H}$ and le Bourhis $\mathrm{X}$ : Tamoxifen and TRAIL synergistically induce apoptosis in breast cancer cells. Oncogene 27: 1472-1477, 2008. 